9 8

21

\section{Densities, diets, and growth rates of larval Alewife and Bloater in a changing Lake} Michigan ecosystem

Suggested Running Head: Larval densities, diets, and growth rates in Lake Michigan

DreW E. EPPEHIMER ${ }^{\mathrm{a}, \mathrm{b}}$, DAVID B. BunNell ${ }^{\mathrm{a}}$, PATRICIA M. ARMENiO ${ }^{\mathrm{a}}$, DAVID M. WARNER ${ }^{\mathrm{a}}$, LAUREN A. EATON ${ }^{\mathrm{c}}$, DAVID J. WELLS ${ }^{\mathrm{d}}$, AND EDWARD S. RUTHERFORD ${ }^{\mathrm{e}}$

8

${ }^{a}$ U.S. Geological Survey, Great Lakes Science Center, 1451 Green Road, Ann Arbor, MI 48105,

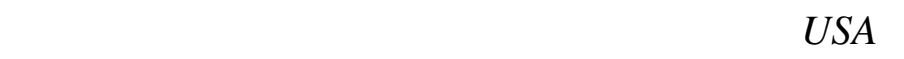

${ }^{b}$ School of Natural Resources and the Environment, University of Arizona, Environment and Natural Resources Building 2, 1064 East Lowell Street, Tucson, AZ 85721, USA

(1)

${ }^{\mathrm{c}}$ University of Toledo, Department of Environmental Science, 2801 West Bancroft Street, Toledo, OH 43606, USA

$9{ }^{\mathrm{d}}$ Cooperative Institute for Great Lakes Research, Great Lakes Environmental Research Laboratory, 4840 South State Road, Ann Arbor, MI 48108, USA

22 e National Oceanic and Atmospheric Administration, Great Lakes Environmental Research Laboratory, 4840 South State Road, Ann Arbor, MI 48108, USA 


\section{Abstract}

25 Variability in abiotic and biotic factors during larval stages have profound impacts on fish

26 recruitment. In Lake Michigan, where the composition of lower trophic levels have undergone

27 considerable changes in the past decade, managers are concerned that fish recruitment could be

28 negatively affected. We hypothesized that spatial variation in Lake Michigan larval fish density

29 and growth can be explained by various environmental predictor variables. In July 2015, we

30 sampled larval fish and zooplankton at 24 sites (distributed among eight transects) around Lake

31 Michigan. We measured larval fish densities and estimated growth rates and diets of the two

32 most abundant species: Alewife Alosa pseudoharengus and Bloater Coregonus hoyi (prey fish

33 that represented $89 \%$ and $4 \%$ of total catch, respectively). Larval Alewife densities at a given site

34 ranged from 0 to 42.57 per $100 \mathrm{~m}^{3}$, but no explanatory variables explained the variation. Alewife

35 mean growth rate equaled $0.50 \mathrm{~mm} / \mathrm{d}$, and fish age and zooplankton density best explained

36 growth variation across sites. Larval Bloater densities ranged from 0 to 1.16 per $100 \mathrm{~m}^{3}$, and

37 mean growth rate equaled $0.21 \mathrm{~mm} / \mathrm{d}$. Across all sites, $67 \%$ of larval Alewife stomachs were

38 empty, whereas only 16\% of Bloater stomachs were empty. Our study reported larval fish growth

39 rates that were at least $40 \%$ slower than those reported in previous decades for both Alewife and

40 Bloater. Worsening prey environment for pelagic larvae such as Alewife and Bloater during the

41 era of abundant dreissenid mussels could reduce the probability of strong year-classes, which in

42 turn may affect growth and survival of recreationally important salmonine predators. 
Introduction

Fish recruitment dynamics within the Laurentian Great Lakes are exceedingly complex and more closely resemble those in large marine systems than traditional, lentic freshwater

47 environments (Janssen et al. 2014; Ludsin et al. 2014; Pritt et al. 2014). Disentangling potential mechanisms underlying the growth and survival of larval fish is important because subtle

49 variability in abiotic and biotic factors during larval stages may exert tenfold effects on fish 50 recruitment (Houde and Hoyt 1987; Houde 1989). For example, the Hjort-Cushing hypothesis

51 asserts that the success of a year class is determined by the availability of food resources during

52 crucial periods of larvae development (i.e. following yolk-sac absorption), and therefore matches

53 or mismatches in timings of plankton production can have significant recruitment implications

54 (Hjort 1914; Cushing 1990). Several of the Laurentian Great Lakes (e.g., Lake Michigan, Huron,

55 Ontario) have undergone changes in lower trophic levels since the proliferation of nonindigenous

56 dreissenid mussels in the early 2000s, including declines in the spring phytoplankton bloom

57 (Vanderploeg et al. 2010; Rowe et al. 2015) and changes in the densities and community composition of zooplankton (Barbiero et al. 2009, 2012, 2014; Pothoven and Fahnenstiel 2015)

59 which, in turn, could influence the growth and availability of prey during critical larval periods. Lake Michigan is illustrative of one of the Laurentian Great Lakes that has undergone

61 dramatic structural ecosystem changes over the past several decades as a result of declining

62 nutrient inputs, reduction of ice cover, proliferation of nonindigenous species, and large stocking

63 efforts to restore piscivores (Madenjian et al. 2002, 2015; Wang et al. 2012). One key fish

64 management concern is declining biomass of planktivorous prey fish species, such as Alewife

65 Alosa pseudoharengus, Bloater Coregonus hoyi, and Rainbow Smelt Osmerus mordax, that

66 support a multi-million-dollar recreational fishery for Chinook Salmon Oncorhynchus 
67 tshawytscha, Coho Salmon Oncorhynchus kisutch, Lake Trout Salvelinus namaycush, Steelhead

68 Oncorhynchus mykiss, and Brown Trout Salmo Trutta (Thayer and Loftus 2012). Two

69 complementary lakewide surveys (i.e., bottom trawl and hydroacoustics with midwater trawl)

70 reveal biomass of prey fishes in $2010-2017$ to be $\leq 88 \%$ of the biomass estimated in the 1990 s

71 (Madenjian et al. 2018; Warner et al. 2018). Predation on juvenile and adult planktivorous fish is

72 one important driver underlying this declining trend, especially for Alewife (Madenjian et al.

73 2005; Tsehaye et al. 2014). Another untested, yet hypothesized, mechanism is declining

74 recruitment emanating from reduced larval growth and survival as a result of reduced availability

75 of zooplankton prey (see Bunnell et al. 2018). In ecosystems such as Lake Michigan that are

76 experiencing oligotrophication simultaneous with high levels of predator stocking, both top-

77 down and bottom-up regulation can be operating and influencing intermediate trophic levels,

78 such as the prey fish community (Bunnell et al. 2014; Kao et al. 2017).

Larval fish studies in the Laurentian Great Lakes have been intermittent and spanned

80 decades. Comparisons of these studies can reveal how changes in lower trophic levels could be

81 affecting larval fish dynamics. Seminal Lake Michigan studies by Wells (1966), Rice et al.

82 (1987a) and Nash and Geffen (1991) provide insights into the community composition and

83 densities of pelagic larval fish during the 1960s through 1980s, prior to the proliferation of

84 Ponto-Caspian invaders that have significantly altered the lake, such as dreissenid mussels, water

85 fleas, and Round Gobies Neogobius melanostomus. These studies describe a nearshore larval fish

86 community dominated by Alewife and Rainbow Smelt, whereas the offshore community was

87 dominated by Bloater and Deepwater Sculpin Myoxocephalus thompsonii (Rice 1987a; Nash and

88 Geffen 1991). Among these earlier studies, only Rice et al. (1987a) used otoliths to estimate

89 growth and survival of larval fish, and they concluded Bloater were feeding at near optimal rates. 
90 In the 2000s, studies reported the densities and growth rates of larval Alewife (e.g., Höök et al.

91 2007; Weber et al. 2015; Withers et al. 2015) and Yellow Perch Perca flavscens (e.g., Dettmers

92 et al. 2005; Weber et al. 2011) at different locations around Lake Michigan. Diets reported from

93 these studies were not consistent with larvae feeding at optimal levels, given that $79-87 \%$ of

94 Alewife larvae, for example, had empty stomachs (Withers et al. 2015). Furthermore, these

95 studies were designed to evaluate how larval growth rate varied spatially within a region of the

96 lake. Given putative spatial variation in temperature and zooplankton density, it should not be

97 surprising that Alewife growth rates varied across sites in Illinois waters (Weber et al. 2015) and

98 Michigan waters, including drowned-rivermouths that are connected to Lake Michigan (Höök et

99 al. 2007).

100 Across a diversity of ecosystems, temperature, densities of zooplankton prey and larval 101 competitors have been identified as important variables to explain larval fish growth rates. In

102 marine ecosystems, Landaeta et al. (2015) documented faster growth of a larval Pearlsides

103 Maurolicus parvipinnis in warmer, more productive areas of the South Pacific, and Meekan et al.

104 (2003) found that temperature better explained variation in growth of Neon Damselfish

105 Pomacentrus coelestis than chlorophyll or zooplankton abundance on an Australian reef.

106 Furthermore, Pepin (1991) argued that temperature regulates the vital rates of all early life stages

107 of marine fishes. In riverine systems, growth rates of larval American Shad Alosa sapidissima

108 were also positively correlated with zooplankton densities and water temperatures (Crecco and

109 Savoy 1985). Across Midwest reservoirs, temperature explained variation in larval growth of

110 Pomoxis spp., Lepomis spp., and American Gizzard Shad Dorosoma cepedianum (Claramunt and

111 Wahl 2000), and biomass of zooplankton prey explained 64\% of the variation in growth of first-

112 feeding Pomoxis spp.larvae (Bunnell et al. 2003). 
114 distributed around Lake Michigan that we expected to differ in prey densities given their variable

115 proximity to rivermouths with different nutrient loading. We measured larval fish densities and

116 estimated instantaneous growth rates and diets of the two most abundant species: Alewife and

117 Bloater. We hypothesized that larval growth rates would be higher at sites with higher indices of

118 primary and secondary zooplankton production, which contribute to greater prey resources for

119 the larvae. A secondary objective was to compare larval growth rates and densities in 2015 to

120 those estimated in the 1980s and 2000s, with the hypothesis that larval growth rates would be

121 higher in the previous years when the zooplankton community might have been more favorable

122 to higher consumption by larval fish through greater densities and prey overlap.

\section{Methods}

124 Field sampling

125 Twenty-four sites throughout Lake Michigan (Figure 1) were sampled for water

126 temperature, chlorophyll a (herein CHL), zooplankton, and larval fish from July 8-27, 2015

127 during nighttime hours. The sites were organized across eight transects, each with three unique

128 depths (18 m, $46 \mathrm{~m}$, and 91 or $110 \mathrm{~m})$. Moving clockwise around the lake, these transects

129 included Frankfort, MI (offshore of the drowned river mouth Arcadia Lake fed by Bowen’s

130 Creek); Ludington, MI (offshore of the Pere Marquette River); Saugatuck (offshore of the

131 Kalamazoo River), MI; St. Joseph, MI (offshore of the St. Joseph River); Waukegan, IL

132 (offshore of the Waukegan River); Racine, WI (offshore of the Root River); Manitowoc, WI

133 (offshore of the Manitowoc River); Sturgeon Bay, WI (connecting Green Bay). The distance

134 between two adjacent sites within a transect ranged from $5.0 \mathrm{~km}$ (between $18 \mathrm{~m}$ and $46 \mathrm{~m}$ off of

135 Frankfort) to 31.9. km (between $46 \mathrm{~m}$ and $110 \mathrm{~m}$ off of Saugatuck). 
At each of the 24 sites, a profile of the water column temperature and fluorescence was measured with a Seabird bathythermograph. The data collected were bin averaged in $1 \mathrm{~m}$ intervals. After observing the profile, we used a Niskin bottle to collect discrete water samples at 139 up to three vertical depths to sample a range of fluorescence values to compare extracted CHL 140 concentrations to fluorescence values. For each of two replicates per depth, 500-900 mL of water 141 were immediately filtered through a $47 \mathrm{~mm}$ Whatman glass fiber filter. Filters were then placed 142 in a Falcon tube wrapped with foil and frozen at $-80^{\circ} \mathrm{C}$ aboard the USGS R/V Sturgeon for later 143 CHL analysis.

144 Zooplankton were sampled from vertical, whole-water column tows using a conical, 0.5145 m diameter, 2-m length, $153-\mu m$ mesh net retrieved at a speed of $0.5 \mathrm{~m} / \mathrm{s}$. The net was equipped 146 with a calibrated flowmeter to estimate volume of water sampled. After the samples were rinsed 147 into the cod end, the cod end was bathed in a bucket of water and the animals were narcotized 148 with $\mathrm{CO}_{2}$ from antacid before being preserved in 5\% sugar buffered formalin.

149 Larval fish were sampled with a circular, 1-m diameter, 500- $\mu$ m mesh ichthyoplankton

150 (IP) net towed at $4.2 \mathrm{~km} / \mathrm{h}$. A calibrated flowmeter was placed in the mouth of the net to 151 calculate volume sampled. On the bottom of the net, we mounted a mensuration sensor 152 (Netmind) that provided real-time estimates of net depth when paired with a hydrophone towed 153 behind the vessel. At each site, both a surface and "oblique" IP tow were conducted. The surface 154 tows were typically $10 \mathrm{~min}$ in duration and were fished off the starboard side of the vessel to 155 avoid wash from the vessel propeller. The oblique tows were fished behind the vessel and 156 sampled several different discrete layers (4-5 min per layer) from the metalimnion through 157 epilimnion. At $18 \mathrm{~m}$ bottom depth, oblique tows were typically $10 \mathrm{~min}$ in total and fished at $\sim 10$ $158 \mathrm{~m}$ and $7 \mathrm{~m}$ layers. At $46 \mathrm{~m}$ bottom depth, oblique tows were typically $12 \mathrm{~min}$ total and fished at 
$159 \sim 30 \mathrm{~m}, 20 \mathrm{~m}$, and $10 \mathrm{~m}$ layers. At the most offshore depth (i.e., 91 or $110 \mathrm{~m}$ bottom depth),

160 oblique tows were typically $16 \mathrm{~min}$ total and fished at $40 \mathrm{~m}, 30 \mathrm{~m}, 20 \mathrm{~m}$, and $10 \mathrm{~m}$ layers. At the

161 end of each IP tow type, the net was rinsed from the outside to concentrate larvae in the cod end,

162 which were promptly preserved in 95\% ethanol.

163

164 Laboratory processing

165 In the laboratory, CHL was extracted in a dark room with $90 \%$ buffered acetone using the 166 modified fluorometric technique from EPA method 445.0 (Arar and Collins 1997). In addition,

167 filters went through a freeze-thaw cycle to break cell walls prior to extraction instead of grinding

168 filters. Fluorescence values were estimated with a fluorometer (Turner Trilogy) that was

169 calibrated with commercial standards to calculate CHL concentrations $(\mu \mathrm{g} / \mathrm{L})$. Replicates were

170 averaged to determine mean concentrations at specific vertical depths at each site.

171 To process zooplankton, the samples were first stained with Phloxine B to improve

172 identification of animals. The entire sample was then inspected for "clumps" of large predatory

173 cladocerans (i.e., Bythotrephes longimanus or Cercopagis pengoi) that could affect subsampling;

174 when "clumps" were found, they were removed for later processing (after ensuring smaller

175 crustacean zooplankton were not attached). The remaining "clump-free” zooplankton sample

176 was then diluted with reverse-osmosis water to between 30-750 mL, with the goal of obtaining a

177 solution with about 200 crustacean zooplankters per mL. The sample was mixed by moving a

178 glass rod in a figure-8 pattern, and a 1-mL aliquot was removed with a Hensen-Stempel pipette.

179 All individual crustacean zooplankton from the sub-sample were identified to the highest

180 taxonomic resolution possible (see below) and counted under a dissecting microscope. Copepod

181 nauplii, dreissenid veligers, and rotifers were not counted because of the large mesh size of the 
182 zooplankton net. All adults were identified to species (except for Bosmina spp.), and copepodites

183 (immature copepods) were identified to genus in a few instances (i.e., Mesocyclops,

184 Tropocyclops, Limnocalanus, Epischura, Senecella) but were otherwise identified as cyclopoid

185 or calanoid copepodites. If 200 crustacean zooplankters were counted in the first 1-mL

186 subsample, no additional aliquots were processed. Otherwise, aliquots were removed in 1-mL

187 increments and processed until at least 200 individuals (total) were identified and counted. The

188 entire sample (including any “clumps” that were previously removed) was then processed to

189 identify and count predatory cladocerans, noting the instar for Bythotrephes and Cercopagis. For

190 all taxa, the first 20 individuals encountered were measured using an ocular micrometer. We

191 measured cladocerans from either the top of their head or the front of their rostrum to the base of

192 the caudal spine or the distalmost part of their carapace. Bythotrephes was measured from the

193 proximal end of its spine to the base of the 'S-curve' of the spine (Berg and Garton 1988). Body

194 length of Cercopagis was measured (Grigorovich et al. 2000). We measured copepods from the

195 anterior-most part of cephalosome to the distal end of the caudal ramus.

196 Larval fish in the IP samples were removed while using an overhead magnifier light.

197 Ninety-nine percent of larval fish were identified to species level using Auer (1982). The

198 remaining larvae unable to be identified were excluded from subsequent analyses. We measured

199 total length of all larval fish to the nearest $0.01 \mathrm{~mm}$ using a dissecting microscope and ImagePro

200 software and corrected these lengths for 10\% shrinkage after preservation in 95\% ethanol (Foley

201 et al. 2010). Alewife and Bloater were the most abundant species, and therefore subsequent age

202 and diet analyses focused only on these two species.

203 A subset of up to 30 Alewife and Bloater from each IP tow were randomly selected for

204 age examination. In total, ages from 464 Alewife larvae and 72 Bloater larvae were estimated 
205 using sagittal otoliths. Daily rings on larval otoliths were counted following a protocol adapted

206 from Höök et al. (2007). Using a dissecting scope, sagittal otoliths were removed from each larva

207 and mounted on glass slides with super glue. Daily growth rings were counted using a Nikon

208 Eclipse 80i microscope at 400-1200x magnification. Two individuals (DEE, LAT) read the

209 otoliths independently on separate dates. If the difference between the readings was less than

$21010 \%$ (occurred for $63 \%$ of Alewife otoliths and $69 \%$ of Bloater otoliths), the mean of the two

211 readings was used to estimate total number of rings. If the difference was greater than or equal to

$21210 \%$, each reader conducted a second set of independent readings. For $28 \%$ of Alewife otoliths

213 and 24\% of Bloater otoliths, the mean of the second read was used because the difference was

214 less than $10 \%$. Otherwise, a third reader (DJW) performed an independent reading, and the

215 median of the final three independent counts was used as the total number of daily growth rings

216 (9\% and 7\% of Alewife and Bloater otoliths, respectively).

217 Diets of larval fish were examined to evaluate whether any evidence of daytime feeding

218 could still be detected with nighttime collected larvae. From each IP sample, 10 larvae per

219 species were randomly selected for diet evaluation. Stomachs were excised and opened with a

220 scalpel or fine-tip scissors, and the contents were examined under a dissecting microscope. If at

221 least 3 of 10 larvae had countable stomach contents, then up to 30 individuals per fish species

222 were processed. Otherwise, no more individuals were examined from that sample. Diet items

223 found in the stomachs were classified as copepod nauplii, calanoid or cyclopoid copepodite,

224 Leptodiaptomus minutus, L. ashlandi, L. sicilis, Epischura lacustris, Bosmina spp., unidentified

225 copepods (could be adult or copepodites), Polyphemus pediculus, Bythotrephes longimanus,

226 Leptodora kindtii, dreissenid veliger, Keratella spp., or Conochilus spp. 
For different zooplankton species within the stomachs, different body parts were used to

228 identify and count individuals to prevent double-counting. For copepods, the fifth legs and

229 urosome needed to be present to count and identify to species level. The urosome was used to

230 identify and count calanoid and cyclopoid copepodites. To avoid double counting copepods,

231 cephalosomes were counted separate from caudal rami and subtracted from each other. Any extra

232 cephalosomes after subtracting the caudal rami were counted as an unknown copepod. In cases

233 where there was only a part (or parts) of the copepod (e.g., metasome) present and the

234 cephalosome and urosome were absent, it was counted as a single unknown copepod. To qualify

235 as a countable cladoceran, the head and rostrum needed to be present for Bosmina spp., the eye

236 and part of body for Polyphemus pediculus, the body or tail spine with some body tissue attached

237 for Bythotrephes longimanus, and the tail spine for Leptodora kindtii. Dreissenid veliger shells

238 needed to be present, but inside tissue did not need to exist to be countable. Rotifers were

239 identified based on intact organisms. The proportion of empty stomachs was estimated for each

240 species at each site. For non-empty stomachs, the proportion (by count) of each diet category

241 was calculated for each fish and averaged across all non-empty individuals to provide a snapshot

242 of the important prey items.

243 To determine what sizes of sampled zooplankton could theoretically be available to

244 larvae, we measured the mouth gape on a subset of larval Alewife. A small probe was inserted

245 into the mouth of the fish, and the dorsoventral gape was measured to the nearest $0.01 \mathrm{~mm}$ using

246 ImagePro software. Gape was measured on up to 10 larvae from each of five different size

247 classes: 5-10 mm, 11-15 mm, 16-20 mm, 21-25 mm, 26-30 mm for a total of 45 fish.

$249 \quad$ Statistical modeling 
251 corresponding fluorescence value (FL) (at the same vertical depth) from the Seabird

252 bathythermograph, pooled across all sites and depths: $\mathrm{CHL}=(F L \times 0.0883)-0.0854, \mathrm{r}^{2}=0.78, \mathrm{P}$

$253<0.0001$. This enabled us to estimate CHL at 1-m increments within the water column at each 254 site.

255 Larval densities for each fish species at each site were calculated by summing the total 256 number of larvae caught in each tow (i.e., surface and oblique) and dividing by the total volume 257 sampled across the tows. The age (A, in days) of an individual fish was estimated as the number 258 of sagittal daily growth rings counted plus 2 for Alewife (Essig and Cole 1986) or plus 3 for 259 Bloater (Rice et al. 1985). Individual instantaneous growth rate ( $\mathrm{G}$, in $\mathrm{mm} / \mathrm{d}$ ) was estimated as $\mathrm{G}$ $260=\left(L_{c}-L_{h} / A\right)$, where $L_{c}$ equals the corrected length at capture (in mm) and $L_{h}$ equals the length at 261 hatch (in mm). We assumed $\mathrm{L}_{\mathrm{h}}$ equaled $3.5 \mathrm{~mm}$ for Alewife (Auer 1982) and $9.75 \mathrm{~mm}$ for 262 Bloater (Rice et al. 1985).

263 We sought to explain spatial variation in larval Alewife and Bloater mean density and 264 growth with several environmental predictor variables: temperature, CHL, and zooplankton 265 density. Because the age and size distribution of larvae differed across sites and the larval growth 266 rate increased with age, we also included age as a growth predictor variable in addition to the 267 variables above. For each sampling site, the mean larval age (days) and growth rate were 268 calculated from all individuals collected in both the surface and oblique tows. Our growth 269 analyses were limited to those sites where at least three larval ages were determined ( $\mathrm{n}=15$ and $270 \mathrm{n}=8$ for Alewife and Bloater, respectively). Our attempt to conduct growth analyses for Bloater 271 failed owing to insufficient sample size. 
273 that were caught primarily in the surface tows (see Results), we estimated the temperature

274 experienced over their lifetime, rather than simply the water temperature measured on the day of

275 collection. However, we had to assume that where larvae were captured was representative of

276 where larvae spent their lifetime. We used daily estimates of lake surface temperature at each

277 sampling site using a blended in situ and remotely sensed 1-km resolution dataset produced by

278 NASA’s Jet Propulsion Laboratory Regional Ocean Modeling System (Chao et al. 2009). These

279 daily lake surface temperatures were cross checked with hourly buoy temperature data from the

280 nearest Lake Michigan buoy maintained by the NOAA National Data Buoy Center. For each

281 larva with an estimated age, daily lake surface temperatures were averaged from estimated hatch

282 date to sampling date at each site. For Bloater, which were primarily captured in oblique tows

283 (see Results), we were unable to utilize lake surface temperatures. Instead we calculated the

284 mean temperature from our fishing depths as measured on the date of sampling with a CTD.

285 For CHL and zooplankton density, we were only able to estimate the variables on the

286 night of collection. The estimated CHL was averaged from the surface to the maximum fishing

287 depth at each transect-depth. For zooplankton, the mean numeric density of prey was calculated

288 to estimate prey small enough to be eaten by gape-limited Alewife larvae. Schael et al. (1991)

289 documented the importance of gape limitation for prey selectivity and determined that gape size

290 in larval fish predicted the upper limits of prey sizes. Our gape-limited zooplankton densities for

291 Alewife remove potential bias by eliminating individuals larger than the gape size. The gape

292 versus Alewife total length regression revealed a linear relationship: Gape $=0.067 \times \mathrm{TL}_{\mathrm{c}}-0.187$

$293\left(r^{2}=0.71, P<0.0001\right)$. For each site, the mean gape of the larvae was estimated based on their

294 mean length. Mean gapes ranged from 0.31-1.17 $\mathrm{mm}$ across sites with a grand average equal to 
$2950.57 \mathrm{~mm}$. For each zooplankton taxon at a given site, the proportion of lengths that were less

296 than or equal to the mean gape was estimated, and the areal density $\left(\# / \mathrm{m}^{2}\right)$ was reduced

297 proportionally. The densities of each taxa were then summed. For bloater, gape measurements

298 were not made, in part because the minimum size of Bloater was relatively large (10.2 mm

299 versus $4.8 \mathrm{~mm}$ for Alewife), and we expected minimal gape limitation based on the large diet

300 items we encountered. Hence, zooplankton prey density for the Bloater density model included

301 all potential zooplankton prey. For both species, we recognize our estimates of available

302 zooplankton are biased low owing to the absence of nauplii, rotifer, and veliger counts because

303 of the zooplankton net mesh size.

304 We used generalized additive models (GAM) in the statistical program $\mathrm{R}$ with the

305 package mgcv (i.e., mixed GAM Computational Vehicle, Wood 2006; 2008) to explore spatial

306 variation in larval Alewife density and growth and larval Bloater density. GAMs function as

307 generalized linear models with linear predictors involving a sum of smooth functions (s) of

308 covariates (Wood 2006). Gam.check was used to optimize smoothness selection (k) and identify

309 any potential issues with model fitting (Wood 2006). With the R package MuMin (Multi-Model

310 Inference), we used Akaike information criterion corrected for small sample size (AICc) to

311 identify the most parsimonious model(s) (Anderson and Burnham 2002; Burnham and Anderson

312 2004). To confirm that our sites exhibited no spatial autocorrelation in larval densities or

313 growth, despite the transect design, we calculated correlograms within R package ncf (Spatial

314 Covariance Functions; Bjornstad 2018). For each response variable, we evaluated the spatial

315 distribution of GAM residuals and whether any pattern emerged between the correlation and 316 distance class. 
For both density models, we included sites where 0 larvae were sampled. Our full model

318 for Alewife density included temperature, gape limited zooplankton densities, and CHL as

319 predictor variables: Density s(Temp, k=4) + s(logZooplankton, k=4) + s(logCHL, k=4). CHL

320 and Zooplankton were log10 transformed to improve the normality of these predictor variables.

321 For Alewife sites where no larvae were sampled, we estimated temperature and zooplankton

322 densities based on relevant Alewife data from the closest non-zero density site. Our full model

323 for Bloater density included temperature, zooplankton densities, and CHL as predictor variables:

324 Density s(Temp, k=4) + s(logZooplankton, k=4) + s(logCHL, k=4).

325 Our full model to explain variation in Alewife growth included the same predictor 326 variables as for density, but we removed CHL, added Alewife density (Density) and mean 327 Alewife age (Age), and weighted the data based on the number of larvae that were used to 328 estimate the mean growth rate at each site: Growth $\sim$ s(logDensity, $k=3)+s($ Temperature, $k=3)$ $329+\mathrm{s}(\operatorname{logZooplankton,~} \mathrm{k}=3)+\mathrm{s}($ Age, $\mathrm{k}=4)$, weights=n. Alewife density and zooplankton density 330 were log10 transformed to improve normality. Alewife density was added to account for 331 potential density dependent control of growth, and age was added to account for potential 332 changes in growth rate associated with ontogeny. We removed CHL because of model 333 overfitting concerns (from too many predictors) and because we assumed zooplankton could 334 characterize site productivity in relation to growth rates.

In the vertical strata where IP were sampled, CHL ranged from 0.49 to $1.56 \mu \mathrm{g} / \mathrm{L}$, while 338 temperature ranged from 14.9 to $18.3^{\circ} \mathrm{C}$. Zooplankton density in the whole water column ranged 339 from 1,509.6 to 131,395.4 individuals $/ \mathrm{m}^{2}$. A total of 2,047 larval fish were captured in surface 
and oblique tows and identified to species. Eighty-nine percent of larvae were identified as

341 Alewife ( $n=1,813), 4 \%$ as Bloater $(n=83)$, and the remaining proportion was comprised of

342 Burbot Lota lota (n=62), Yellow Perch (n=50), Deepwater Sculpin (n=27), Slimy Sculpin Cottus

343 cognatus $(\mathrm{n}=11)$, and Common Carp Cyprinus carpio $(\mathrm{n}=1)$. Alewife larvae were relatively

344 evenly distributed across bottom depths (526 at $18 \mathrm{~m}, 653$ at $46 \mathrm{~m}$, and 634 at $\geq 91 \mathrm{~m}$ ), but 1,650

345 of the total 1,813 (91\%) were collected from surface tows. In contrast to Alewife, 74 of the 83

346 Bloater larvae (89\%) were collected at the farthest offshore sites ( $\geq 91 \mathrm{~m}$ bottom depth), only 8

347 were captured at $46 \mathrm{~m}$, and 1 at $18 \mathrm{~m}$; 67 of the larvae (81\%) were captured in oblique tows.

348 Burbot were captured most commonly at $\geq 91 \mathrm{~m}$ bottom depth (36 individuals, versus 21 at $46 \mathrm{~m}$ 349 and 5 at $18 \mathrm{~m}$ ) and in oblique tows (54 of 62 total larvae, 87\%). Finally, Yellow Perch larvae 350 were captured most frequently at $18 \mathrm{~m}$ bottom depth ( 35 of 50, versus 13 at $46 \mathrm{~m}$ and 2 at $\geq 91$ $351 \mathrm{~m})$ and in surface tows 45 of 50 total larvae (90\%).

352 Larval Alewife densities at a given site ranged from 0 to 42.57 per $100 \mathrm{~m}^{3}$ (Table 1, 353 Figure 2). Densities exceeded 10 per $100 \mathrm{~m}^{3}$ at four sites in southern Lake Michigan: $46 \mathrm{~m}$ at St. 354 Joseph, $18 \mathrm{~m}$ at St. Joseph, $91 \mathrm{~m}$ at Waukegan, and $18 \mathrm{~m}$ at Saugatuck (Table 1). At the 355 northernmost sites, no larvae were collected at Sturgeon Bay, and only 1 larva was collected at 356 Frankfort. An information-theoretic approach to explain larval Alewife density revealed the 357 highest ranked model included only the intercept (Table 2), and the residuals exhibited no spatial 358 autocorrelation. Three other models also had $\Delta \mathrm{AICc}<2$, each with only one explanatory variable 359 of either temperature, zooplankton, or CHL. But variation explained was relatively low, with 360 only $14 \%$ of the deviance explained in the full model.

361 Across all larval Alewife that were processed for age $(n=464)$, mean growth rate 362 equaled $0.50 \mathrm{~mm} / \mathrm{d}$ (SE, 0.01). Growth rates varied across sites (Table 1, Figure 2), and Alewife 
363 larvae from St. Joseph grew the fastest ( $0.56 \mathrm{~mm} / \mathrm{d}$ across all depths). Mean age (24 days) and 364 size $(17.0 \mathrm{~mm})$ were also greatest for Alewife from St. Joseph. Alewife larvae from Manitowoc 365 also grew at a relatively fast rate $(0.51 \mathrm{~mm} / \mathrm{d}$, with mean age and length $=12$ days, $9.6 \mathrm{~mm}$, 366 respectively) but were only collected at the deepest depth (Table 1$)$. Waukegan $(0.48 \mathrm{~mm} / \mathrm{d}, 10$ 367 days, $8.2 \mathrm{~mm})$ and Racine $(0.46 \mathrm{~mm} / \mathrm{d}, 12$ days, $9.0 \mathrm{~mm})$ larval Alewife growth rates were also 368 relatively fast. Alewife larvae from Ludington sites had the slowest mean growth rate (0.37 $369 \mathrm{~mm} / \mathrm{d}, 12$ days, $8.1 \mathrm{~mm})$.

370 Using an information-theoretic approach to explain mean growth rates of Alewife larvae 371 across the sites, our full growth model explained $92.7 \%$ of the deviance. One model 372 outperformed all the others, and it included both age and zooplankton density as predictors 373 (Table 3). Of the models with $\triangle$ AICc $<6,2$ out of 3 included age, and 2 out of 3 included 374 zooplankton density, which further reinforces their importance as explanatory variables (Table 375 3). Furthermore, larval Alewife growth had a positive linear relationship with zooplankton 376 density (Figure 3a). The relationship between Alewife age and growth was non-linear showing a 377 negative correlation with young larvae ( $<15$ days) and a positive correlation with old larvae $(>20$ 378 days) (Figure 3b). For the best performing model, the residuals exhibited no spatial 379 autocorrelation.

$380 \quad$ Sixty-seven percent of larval Alewife stomachs $(n=313)$ were empty, although 381 considerable variation was observed across sites (Table 1). Among the 12 sites that had at least 38210 diets analyzed, only two sites had less than $50 \%$ of larvae with empty stomachs, and both of 383 those sites were offshore: $110 \mathrm{~m}$ at Saugatuck and $91 \mathrm{~m}$ at Waukegan (Table 1). Among the 384 Alewife stomachs that were not empty, the taxa with the highest mean proportion were 385 dreissenid veligers (39.2\%), unidentifiable copepods (27.8\%), cyclopoid copepodites (13.3\%), 
and calanoid copepodites (5.5\%; see Supplementary Table 1). In addition to veligers having the

387 highest mean proportion within a diet, they were also observed in 56\% of the Alewife stomachs 388 that were not empty.

Bloater larvae were collected at 13 sites across all eight ports, and their densities were generally lower than those estimated for Alewife. Two exceptions were more northerly ports

391 (Ludington and Sturgeon Bay), where densities for Bloater were comparable to or higher than 392 those for larval Alewife. The highest Bloater density was 1.16 per $100 \mathrm{~m}^{3}$ at $110 \mathrm{~m}$ at Saugatuck 393 (Table 1). Similar to the Alewife density model, the highest ranked model included only the 394 intercept (Table 4), and the residuals exhibited no spatial autocorrelation. The explanatory power 395 of the full model was very low (8.19\% of the deviance explained), and all of the model weights 396 were small. Across all larval Bloater that were aged $(\mathrm{n}=72)$, mean growth rate equaled 0.21 $397 \mathrm{~mm} / \mathrm{d}(\mathrm{SE}, 0.01)$. The fastest mean growth rates $(0.27 \mathrm{~mm} / \mathrm{d})$ occurred on the western side of the 398 lake: $91 \mathrm{~m}$ at Waukegan, $91 \mathrm{~m}$ at Racine, $110 \mathrm{~m}$ at Manitowoc. The slowest mean growth rates 399 were $0.17 \mathrm{~mm} / \mathrm{d}$ at $110 \mathrm{~m}$ at both Ludington and St. Joseph. Only $16 \%$ of larval Bloater stomachs $(n=81)$ were empty. Most of the Bloater diets that 401 were processed came from only three sites (Table 1), which ranged from only 0-29\% empty 402 (Table 1). Among the stomachs that were not empty, the taxa with the highest mean proportion 403 were unidentifiable copepods (51.3\%), cyclopoid copepodites (28.1\%), dreissenid veligers 404 (9.2\%), and calanoid copepodites (4.5\%; see Supplementary Table 1). Unidentified copepods 405 were found in 91\% of the stomachs, whereas the most common Alewife prey, dreissenid 406 veligers, only occurred in 35\% of Bloater stomachs.

\section{Discussion}


Our hypothesis that larval Alewife densities and growth rates would be higher at sites

410 with higher primary and secondary production was partially supported. Zooplankton density was

411 included among the best models to explain larval Alewife growth rates, and the relationship was

412 positive, as predicted. Conversely, variation in larval Alewife and Bloater densities were not

413 explained by any of our predictor variables, including CHL and zooplankton densities. Our

414 secondary objective was to compare larval growth rates in 2015 to those from previous decades,

415 given that some time series surveys of zooplankton have revealed declining trends since the

416 1980s or 1990s (Dettmers et al. 2003; Madenjian et al. 2015; Bunnell et al. 2018).

417 We found evidence for reduced growth rates for both Alewife and Bloater. Weber et al.

418 (2015) reported mean larval Alewife growth rates as $0.81 \mathrm{~mm} / \mathrm{d}$ (SE, 0.08) in 2005 and 1.11

$419 \mathrm{~mm} / \mathrm{d}(\mathrm{SE}, 0.11)$ in 2006 offshore of Waukegan, IL. At approximately this same location in

420 2015, we estimated mean larval Alewife growth rates as $0.49 \mathrm{~mm} / \mathrm{d}$ (SE, 0.02), which was a 47\%

421 decline. From 1989 to 1992, Alewife larvae collected in southeastern Lake Michigan had growth

422 rates of 0.8-0.9 mm/d (D. Jude, unpublished data as cited by Höök et al. 2007), and Höök et al.

423 (2007) reported $0.89 \mathrm{~mm} / \mathrm{d}(\mathrm{SE}, 0.06)$ and $0.84 \mathrm{~mm} / \mathrm{d}(\mathrm{SE}, 0.06)$ growth rates near Muskegon,

424 MI in 2001 and 2002, respectively. Although our sampling sites did not include Muskegon, the

425 average growth rate from our two southeastern sites (Saugatuck and St. Joseph) was $0.52 \mathrm{~mm} / \mathrm{d}$

426 (SE, 0.01), which was approximately a 35-42\% decline from 1989-1992 and a 40\% decline from

427 2001-2002. A similar growth reduction was noted for Bloater larvae in Lake Michigan. Rice et

428 al. (1987a) reported larval growth rates averaging $0.50 \mathrm{~mm} / \mathrm{d}$ (SE, 0.01) in 1982 and $0.45 \mathrm{~mm} / \mathrm{d}$

429 (SE, 0.01) in 1983 northeast of Racine, WI (digitized data from Figure 6 in Rice et al. 1987a). In

430 2015, Bloater larvae were relatively rare among our samples, and we caught only 17 individuals

431 offshore of Racine with an average growth rate of $0.27 \mathrm{~mm} / \mathrm{d}$ (SE, 0.02), which was a $43 \%$ 
432 decline from the early 1980s. When all Bloater larvae (N=72) from Lake Michigan in 2015 were

433 pooled, the average growth rate was even slower: $0.21 \mathrm{~mm} / \mathrm{d}$ (SE, 0.01). When comparing these

434 two species in our study, mean Alewife growth rate was more than twice that of Bloater, which

435 is consistent with faster mean larval growth by Alewife when comparing previous studies. One

436 possible explanation for faster Alewife growth is a warmer thermal environment for Alewife

437 given that $91 \%$ of Alewife were captured in the warmer epilimnion, whereas $81 \%$ of Bloater

438 were captured by oblique tows in colder, sub surface waters.

$439 \quad$ Alewife hatch dates across our sampling sites showed a bimodal distribution

440 distinguishing eastern vs. western Lake Michigan (Figure 4). Alewife from eastern Lake

441 Michigan hatched earlier with a peak on June $24^{\text {th }}$, while those from western Lake Michigan

442 hatched later with a peak on July $12^{\text {th }}$. The nearshore water temperature estimated on the modal

443 hatch date were all between 15 and $19^{\circ} \mathrm{C}$ (Table 5), which corresponds to the temperature range

444 of 15 to $22^{\circ} \mathrm{C}$ at which previous studies have documented peak Alewife hatching in Lake

445 Michigan (Weber et al. 2015). Future research could seek to determine whether the earlier

446 hatching on the eastern coastline is a consistent pattern. In general, the western coastline may be

447 cooler, on average, owing to its higher frequency of upwelling events given the prevailing wind

448 patterns (Plattner et al. 2006).

449 Comparisons of our 2015 larval densities to previous Lake Michigan studies indicate

450 similar Alewife densities and lower Bloater densities. For Alewife, we can make comparisons in

451 the southern basin between daytime estimates from previous studies and nighttime estimates in

452 our study, recalling that 91\% of Alewife larvae caught in 2015 were in surface tows. As larvae

453 catchability has been shown to increase during nighttime (Martin et al. 2011), we cannot rule out

454 methodological differences when our larval density estimates are higher. In the southeastern 
455 nearshore, larval Alewife densities in July 1983 at the surface ranged from 3.3 larvae per $100 \mathrm{~m}^{3}$

456 off of Grand Haven, MI (Nash and Geffen 1991) to 200 larvae per $100 \mathrm{~m}^{3}$ (SE, 90) in the

457 summer of 2002 off of Muskegon, MI (Höök et al. 2007). The average of our 2015 estimates

458 from the two southeastern sites was 32.1 larvae per $100 \mathrm{~m}^{3}$ (SE, 9.2). At Waukegan (in

459 southwestern Lake Michigan), peak Alewife densities in the summers of 2005-2006 were 0.3-2.1

460 larvae per $100 \mathrm{~m}^{3}$ in the nearshore (surface only) and 4.0-16.0 larvae per $100 \mathrm{~m}^{3}$ in the offshore

461 (tucker trawl in midwater plus neuston net in surface, Weber et al. 2015). In 2015, our nearshore

462 (i.e., 0.3 larvae per $100 \mathrm{~m}^{3}$, surface only) and offshore (i.e., 15.4 larvae per $100 \mathrm{~m}^{3}$, oblique and

463 surface combined) Alewife densities were within the range observed by Weber et al. (2015).

464 For Bloater, we can compare our July 2015 study to one in July 1983 in southeastern

465 Lake Michigan that sampled larvae during the daytime at the surface with a neuston net, as well

466 as the epi-, meta-, and hypolimnion with a tucker trawl at five sites off of Grand Haven, MI

467 (Nash and Geffen 1991). To compare our estimates from oblique tows (where we caught 81\% of

468 bloater larvae in 2015) to Nash and Geffen (1991), we averaged their densities from the

469 metalimnion and epilimnion layers. Every comparison between 2015 and 1983 revealed

470 significantly lower densities in 2015. In surface tows, we only caught Bloater larvae at the $46 \mathrm{~m}$

471 and $110 \mathrm{~m}$ sites at our southeastern locations, but our non-zero densities (i.e., 0.17 and 0.87

472 larvae per $100 \mathrm{~m}^{3}$, respectively) were orders of magnitude lower than the 1983 densities (i.e.,

47334.9 and 1,551.9 larvae per $100 \mathrm{~m}^{3}$ at the $50 \mathrm{~m}$ and $100 \mathrm{~m}$ site, respectively). Bloater densities at

474 every other 1983 sampling site ranged $0-1,551$ larvae per $100 \mathrm{~m}^{3}$. Larval Bloater densities were

475 undoubtedly higher in the 1980s than in 2015, whereas Alewife densities were comparable

476 between 1983 and 2015. However, larval densities typically exhibit high interannual variability. 
477 Further research is needed to see if our results are a single-year event or are indicative of a larger 478 decline in productivity for Bloater.

479 Our finding that larval growth increased with relatively greater densities of zooplankton 480 is consistent with a broad range of studies, but our inability to detect a temperature effect on 481 growth was surprising and should not be excluded as a hypothesis in future research. The shape 482 of the nonlinear relationship between Alewife age and growth (Figure 3b) was unexpected; a 483 more common nonlinear relationship between age and length is sigmoidal or logistic (Quist et al. 484 2012). One potential explanation for the initial growth decline that we observed is that young 485 larvae were gape limited following yolk-sack absorption and had fewer prey resources available 486 for consumption thus reducing growth rates.

487 Spatial variation in larval Alewife growth rates in 2015 was explained by zooplankton 488 prey densities, and larval growth rates (on average) were at least 40\% lower in 2015 than in 489 previous years. One unequivocal change in Lake Michigan since the late 1990s has been 490 declining primary production in spring, owing to declining nutrient inputs and increasing 491 herbivory by nonindigenous dreissenid mussels (Fahnenstiel et al. 2010; Rowe et al. 2015; 492 Warner and Lesht 2015). Even though declining secondary production (such as zooplankton) 493 might be expected given declining primary production, the evidence for this pattern is equivocal 494 and only partially supports the hypothesis that reduced larval Alewife and Bloater growth rates in 4952015 were the result of declining prey availability (see Bunnell et al. 2018).

497 zooplankton prey could be contributing to reduced larval growth rates in 2015 relative to 498 previous decades. Many zooplankton species have been documented to migrate to deeper, 499 darker, and colder waters in the hypolimnion to avoid predation from Bythotrephes longimanus, 
500 a large predatory cladoceran (Pangle and Peacor 2006; Bourdeau et al. 2011, 2015). In addition,

501 the irruption of quagga mussels since 2004 has increased water clarity and depth of the euphotic

502 zone by $5 \mathrm{~m}$ (Yousef et al. 2017), which could be inducing zooplankton to migrate to deeper

503 waters to reduce exposure to ultraviolet radiation (Leech and Williamson 2001) or reduce

504 vulnerability to visual predators.

505 We have circumstantial evidence that fish larvae sampled deeper in the water column at

506 night have more feeding opportunities than those in the top meter of water. More than $80 \%$ of

507 Bloater larvae were sampled in our oblique tows, which fished down to $40 \mathrm{~m}$ of water in the

508 offshore, to $35 \mathrm{~m}$ of water in the intermediate site, and $10 \mathrm{~m}$ of water in the nearshore. Only $16 \%$

509 of Bloater larvae had empty stomachs. Conversely, more than 90\% of Alewife larvae were

510 caught in the surface tow at night, and $67 \%$ of all Alewife larvae had empty stomachs. We do not

511 think this discrepancy was due to time of sampling because, on average, oblique tows were

512 conducted one hour later in the night than surface tows, and those later-collected larvae might be

513 expected to have more of their prey digested, given that feeding is highest during the day (Boeuf

514 and Le Bail 1999). Nonetheless, our high percentage of empty stomachs for Alewife larvae

515 corroborate earlier findings from daytime collections during the 2000s: 66-87\% empty in 2001-

5162002 (Höök et al. 2007) and 79-87\% in 2010-2011 (Withers et al. 2015). Decreasing spatial

517 overlap between zooplankton prey and larval Alewife could explain high empty stomach rates.

518 It is important to examine not just the presence/absence of food in larval fish stomachs,

519 but also the relative quality of the prey items. For example, the most common prey item in larval

520 Alewife diets was dreissenid mussel veligers, a similar result to what Withers et al. (2015)

521 reported in their 2010-2011 sampling of southeast Lake Michigan. Veliger densities are not well

522 monitored in the Great Lakes, but it is logical to conclude that their densities have increased 
523 concomitant with increasing densities of dreissenid mussels in Lake Michigan (Nalepa et al.

524 2009). The short- or long-term consequences of relying on veligers for larval fish nutrition is not

525 well understood. For example, how well can larval fish digest veligers or what is their energy

526 density relative to comparably sized copepod nauplii or large rotifers? Studies on the

527 consumption of adult dressenid mussels by adult fishes have been linked to decreased growth

528 rates (Pothoven and Madenjian 2008). Alternatively, Withers et al. (2015) speculated that

529 veligers could represent an abundant prey source for larval fish that may help offset lower

530 availability of other prey. Veligers may be important for larval growth, and we acknowledge that

531 if they are an important nutritional source, our growth analysis should be revisited so that density

532 of prey can include both veligers and copepod nauplii.

533 Larvae that are not feeding could be vulnerable to starvation, especially larvae that hatch

534 out at small sizes (Miller et al. 1988). First-feeding Alewife between 3-5 mm in size (Auer 1982)

535 may be particularly vulnerable to starvation during this critical period, especially when one

536 considers the higher percentage of empty stomachs that our study and others have observed. A

537 laboratory study documented that under ideal water temperatures $\left(15^{\circ} \mathrm{C}\right)$, unfed larval Alewife

538 survived an average of 7.6 days after hatch (Edsall 1970). Whereas, another lab study showed

539 that $50 \%$ of Bloater larvae survived without food for up to 25 days after hatch (Rice et al.

540 1987b), and a concurrent field study concluded starvation was not an important source of

541 mortality (Rice et al. 1987a). However, if Bloater larvae are indeed growing $40 \%$ more slowly

542 than they were in the 1980s, then some negative effects on survival are very possible. For

543 example, slower growth rates and resultant smaller sizes can increase their vulnerability to

544 predation (Crowder et al. 1987). 
The role of currents in transporting larvae in the Great Lakes also has been hypothesized

546 to play an important role in fish recruitment (Ludsin et al. 2014). Current-driven transport of

547 ichthyoplankton in the Great Lakes has been documented for several species (e.g., Alewife,

548 Yellow Perch, Cisco Coregonus artedi) and can influence their growth and survival by affecting

549 their thermal and prey environment (Dettmers et al. 2005; Oyadomari and Auer 2008; Weber et

550 al. 2011). Alewife spawn in the nearshore waters of Lake Michigan in mid-summer (Auer 1982).

551 Similar to Weber et al. (2015), we observed advection of young Alewife larvae to offshore

552 sampling stations: 21\% of offshore larvae were aged 10 days or younger. Because Alewife larvae

553 typically occupy the epilimnion (Martin et al. 2011, this study), wind-driven surface currents

554 may be the primary mechanism (Weber et al. 2015) for advection of the larval fish. Heufelder et

555 al. (1982) documented advection of Alewife larvae following upwelling events and hypothesized

556 they increased mortality through thermal shock and/or movement into less favorable habitat.

557 Future research that synthesizes physical current models with biological vital rates of fishes

558 could improve the understanding of whether offshore transport has a net positive or negative

559 effect on larval fish survival.

560 In conclusion, managers in Lake Michigan are increasingly concerned about the impact

561 of declining primary production and changing zooplankton community on the production of prey

562 fishes (Bunnell et al. 2018), and our study supported the hypothesis that growth rates of larval

563 Alewife are limited by zooplankton prey density. Furthermore, our study reported larval fish

564 growth rates in 2015 that were at least 40\% slower than those reported in previous decades, for

565 both Alewife and Bloater. Recognizing that fish recruitment is regulated by a suite of interacting

566 abiotic and biotic factors (see Crowder et al. 1987; Letcher et al. 1996), slower larval growth,

567 alone, is not sufficient to explain declining Alewife biomass in Lake Michigan (see Madenjian et 
568 al. 2006; Collingsworth et al. 2014; Tsehaye et al. 2014). Nonetheless, we hypothesize that

569 unless veligers represent a nutritional prey resource for larval fish, the dreissenid era will reduce

570 the probability of strong year-classes emerging for pelagic larvae such as Alewife and Bloater

571 when other conducive environmental variables might otherwise be present. To test this

572 hypothesis, future larval fish monitoring that spans a broad spatial and temporal scale will need

573 to be developed to evaluate possible linkages between larval growth, larval density, and year-

574 class strength.

575

576 Acknowledgements

577 We thank Carly Nowicki for assistance with field work and the vessel crew of the USGS

578 RV Sturgeon that so expertly supported the intensive 2015 sampling year on Lake Michigan:

579 Shawn Parsons, Lyle Grivicich, and Erin Grivicich. The U.S. EPA supported this research

580 through the Great Lakes Restoration Initiative. Comments from Ed Roseman and three

581 anonymous reviewers greatly improved this manuscript.

582

\section{References}

584 Anderson, D. R., and K. P. Burnham. 2002. Avoiding pitfalls when using information-theoretic 585 methods. The Journal of Wildlife Management 66: 912-918.

586 Arar, E. J. and G. B. Collins. 1997. Method 445.0: In vitro determination of chlorophyll $a$ and pheopyhtin $a$ in marine and freshwater algae by fluorescence. National Exposure

588 Research Laboratory, U.S. Environmental Protection Agency, Cincinnati, OH.

589 Auer, N. A. 1982. Identification of larval fishes of the Great Lakes basin with emphasis on the $590 \quad$ Lake Michigan drainage. Great Lakes Fishery Commission Special Publication 82-3. 
591 Barbiero, R. P., M. Balcer, D. C. Rockwell, and M. L. Tuchman. 2009. Recent shifts in the 592 crustacean zooplankton community of Lake Huron. Canadian Journal of Fisheries and Aquatic Sciences 66: 816-828.

594 Barbiero, R. P., B. M. Lesht, and G. J. Warren. 2012. Convergence of trophic state and the lower food web in Lakes Huron, Michigan, and Superior. Journal of Great Lakes Research 38: 368-380.

Barbiero, R. P., B. M. Lesht, and G. J. Warren. 2014. Recent changes in the offshore crustacean zooplankton community of Lake Ontario. Journal of Great Lakes Research 40: 898-910.

Berg, D. J., and D. W. Garton. 1988. Seasonal abundance of the exotic predatory cladoceran, Bythotrephes cederstroemi, in western Lake Erie. Journal of Great Lakes Research 14: 479-488.

Bjornstad, O. N. 2018. Pckage 'ncf'. Spatial covariance functions version 1.2-6.

Boeuf, G. and P. Y. Le Bail. 1999. Does light have an influence on fish growth? Aquaculture 177: $129-152$.

Bourdeau, P. E., K. L. Pangle, and S. D. Peacor. 2011. The invasive predator Bythotrephes induces changes in the vertical distribution of native copepods in Lake Michigan. Biological Invasions 13: 2533-2545.

611 Bunnell, D. B., M. J. Gonzalez, and R. A. Stein. 2003. Zooplankton influences growth, but not survival, of first-feeding Pomoxis spp. larvae. Canadian Journal of Fisheries and Aquatic Sciences 60: 1314-1323. 
614 Bunnell, D. B., R. P. Barbiero, S. A. Ludsin, C. P. Madenjian, G. J. Warren, D. M. Dolan, T. O. 615 Brenden, R. Briland, O. T. Gorman, J. X. He, T. H. Johengen, B. F. Lantry, T. F. Nalepa, S. C. Riley, C. M. Riseng, T. J. Treska, I. Tsehaye, M. G. Walsh, D. M. Warner, and B.

Bunnell, D. B., H. J. Carrick, C. P. Madenjian, E. S. Rutherford, R. P. Barbiero, E. HincheyMalloy, S. A. Pothoven, C. M. Riseng, R. M. Claramunt, H. A. Bootsma, A. K. Elgin, M. D. Rowe, S. M. Thomas, B. A. Turschak, S. Czesny, K. L. Pangle, and D. M. Warner. 2018. Are changes in lower trophic levels limiting prey fish biomass and production in Lake Michigan? Great Lakes Fishery Commission Miscellaneous Publication 18-01.

Burnham, K. P. and D. R. Anderson. 2004. Multimodel inference understanding AIC and BIC in model selection. Sociological Methods \& Research 33: 261-304.

Chao, Y., Z. Li, J. D. Farrara, and P. Hung. 2009. Blending sea surface temperatures from multiple satellites and in situ observations for coastal oceans. Journal of Atmospheric and Oceanic Technology 26: 1415-1426.

Claramunt, R. M. and D. H. Wahl. 2000. The effects of abiotic and biotic factors in determining larval fish growth rates: a comparison across species and reservoirs. Transactions of the American Fisheries Society 129: 835-851.

Collingsworth, P. D., D. B. Bunnell, C. P. Madenjian, and S. C. Riley. 2014. Comparative recruitment dynamics of alewife and bloater in Lakes Michigan and Huron. Transactions of the American Fisheries Society 143: 294-309. 
635 Crecco, V. A. and T. F. Savoy. 1985. Effects of biotic and abiotic factors on growth and relative 636 survival of young American shad, Alosa sapidissima, in the Connecticut River. Canadian 637 Journal of Fisheries and Aquatic Sciences 42: 1640-1648.

638 Crowder, L. B., M. E. McDonald, and J. A. Rice. 1987. Understanding recruitment of Lake Michigan Fishes: The importance of size-based interactions between fish and zooplankton. Canadian Journal of Fisheries and Aquatic Sciences 44(S2): s141-s147.

641 Cushing, D. H. 1990. Plankton production and year-class strength in fish populations: an update

643 Dettmers, J. M., M. J. Raffenberg, and A. K. Weis. 2003. Exploring zooplankton changes in southern Lake Michigan: implications for yellow perch recruitment. Journal of Great Lakes Research 29: 355-364.

Dettmers, J. M., J. Janssen, B. Pientka, R. S. Fulford, and D. J. Jude. 2005. Evidence across multiple scales for offshore transport of yellow perch (Perca flavescens) larvae in Lake Michigan. Canadian Journal of Fisheries and Aquatic Sciences 62: 2683-2693.

Edsall, T. A. 1970. The effect of temperature on the rate of development and survival of alewife eggs and larvae. Transactions of the American Fisheries Society 99: 376-380.

Essig, R. J. and C. F. Cole. 1986. Methods of estimating larval fish mortality from daily increments in otoliths. Transactions of the American Fisheries Society 115: 34-40.

653 Fahnenstiel, G. L., S. A. Pothoven, H. A. Vanderploeg, D. Klarer, T. F. Nalepa, and D. Scavia. 2010. Recent changes in primary production and phytoplankton in the offshore region of southeastern Lake Michigan. Journal of Great Lakes Research 36: 20-29. 
656 Foley, C. J., D. J. Ryan, and T. O. Höök. 2010. Length reduction of larval yellow perch and freshwater amphipods in RNA later solution. North American Journal of Fisheries Management 30: 1143-1148.

Grigorovich, I. A., H. J. MacIsaac, I. K. Rivier, N. V. Aladin, and V. E. Panov. 2000. Comparative biology of the predatory cladocerans Cercopagis pengoi from Lake Ontario, Baltic Sea and Caspian Sea. Archive fur Hydrobiologie 149: 23-50.

Heufelder, G. R., D. J. Jude, and F. J. Tesar. 1982. Effects of upwelling on local abundance and

Hjort, J. 1914. Fluctuations in the great fisheries of northern Europe. Rapports et Proce`sverbaux des Re'unions, Conseil Permanent International pour l’Exploration de la Mer 20: $1-228$

Höök, T. O., E. S. Rutherford, D. M. Mason, and G. S. Carter. 2007. Hatch dates, growth, survival, and overwinter mortality of age-0 alewives in Lake Michigan: implications for habitat-specific recruitment success. Transactions of the American Fisheries Society 136:

672 Houde, E. D. and R. D. Hoyt. 1987. Fish early life dynamics and recruitment variability. American Fisheries Society Symposium 2: 17-29.

674 Houde, E. D. 1989. Subtleties and episodes in the early life of fishes. Journal of Fish Biology 35:

$675 \quad 29-38$.

676 Janssen, J., J. E. Marsden, T. R. Hrabik, and J. D. Stockwell. 2014. Are the Laurentian Great 677 Lakes great enough for Hjort? ICES Journal of Marine Science 71: 2242-2251. 
678 Kao, Y., M. W. Rogers, and D. B. Bunnell. 2017. Evaluating stocking efficacy in an ecosystem undergoing oligotrophication. Ecosystems DOI: 10.1007/s10021-017-0173-5.

Landaeta, M. F., C. A. Bustos, J. E. Contreras, F. Salas-Berríos, P. Palacios-Fuentes, M. Alvarado-Niño, J. Letelier, and F. Balbontín. 2015. Larval fish feeding ecology, growth and mortality from two basins with contrasting environmental conditions of an inner sea of northern Patagonia, Chile. Marine Environmental Research 106: 19-29.

Leech, D. M. and C. E. Williamson. 2001. In situ exposure to ultraviolet radiation alters the depth distribution of Daphnia. Limnology and Oceanography 46: 416-420.

686 Letcher, B. H., J. A. Rice, L. B. Crowder, and K. A. Rose. 1996. Variability in survival of larval fish: disentangling components with a generalized individual-based model. Canadian Journal of Fisheries and Aquatic Sciences, 53(4): 787-801.

Ludsin, S. A., K. M. DeVanna, and R. E. Smith. 2014. Physical-biological coupling and the challenge of understanding fish recruitment in freshwater lakes. Canadian Journal of Fisheries and Aquatic Sciences 71: 775-794.

Madenjian, C. P., G. L. Fahnenstiel, T. H. Johengen, T. F. Nalepa, H. A. Vanderploeg, G. W. Fleischer, P. J. Schneeberger, D. M. Benjamin, E. B. Smith, J. R. Bence, and E. S. Rutherford. 2002. Dynamics of the Lake Michigan food web, 1970-2000. Canadian the American Fisheries Society 134: 218-230. 
Madenjian, C. P., S. A. Pothoven, J. M. Dettmers, and J. D. Holuszko. 2006. Changes in seasonal energy dynamics of alewife (Alosa pseudoharengus) in Lake Michigan after invasion of dreissenid mussels. Canadian Journal of Fisheries and Aquatic Sciences 63: 891-902.

Madenjian, C. P., D. B. Bunnell, D. M. Warner, S. A. Pothoven, G. L. Fahnenstiel, T. F. Nalepa, H. A. Vanderploeg, I. Tsehaye, R. M. Claramunt, and R. D. Clark. 2015. Changes in the Lake Michigan food web following dreissenid mussel invasions: A synthesis. Journal of Great Lakes Research 41: 217-231.

Madenjian, C. P., D. B. Bunnell, T. J. Desorcie, P. Armenio, and J. V. Adams. 2018. Status and trends of preyfish populations in Lake Michigan, 2016. A report to the Great Lakes Fishery Commission, Lake Michigan Committee, Sault St. Marie, ON, 2018.

Martin, B. T., S. J. Czesny, and D. H. Wahl. 2011. Vertical distribution of larval fish in pelagic waters of southwest Lake Michigan: Implications for growth, survival, and dispersal. Journal of Great Lakes Research 37: 279-288.

Meekan, M. G., J. H. Carleton, A. D. McKinnon, K. Flynn, and M. Furnas. 2003. What determines the growth of tropical reef fish larvae in the plankton: Food or temperature? Marine Ecology Progress Series 256: 193-204.

Miller, T. J., L. B. Crowder, J. A. Rice, and E. A. Marschall. 1988. Larval size and recruitment mechanisms in fishes: toward a conceptual framework. Canadian Journal of Fisheries and Aquatic Sciences 45: 1657-1670.

Nalepa, T. F., D. L. Fanslow, and G. A. Lang. 2009. Transformation of the offshore benthic community in Lake Michigan: Recent shift from the native amphipod Diporeia spp. to the invasive mussel Dreissena rostriformis bugensis. Freshwater Biology 54: 466-479. 
721 Nash, R. D. and A. J. Geffen. 1991. Spatial and temporal changes in the offshore larval fish 722 assemblage in southeastern Lake Michigan. Journal of Great Lakes Research 17: 25-32.

723 Oyadomari, J. K. and N. A. Auer. 2008. Transport and growth of larval cisco (Coregonus artedi)

724 in the Keweenaw Current region of Lake Superior. Canadian Journal of Fisheries and 725 Aquatic Sciences 65(7): 1447-1458.

726 Pangle, K. L. and S. D. Peacor. 2006. Non-lethal effect of the invasive predator Bythotrephes

727 longimanus on Daphnia mendotae. Freshwater Biology 51: 1070-1078.

728 Pepin, P. 1991. Effect of temperature and size on development, mortality, and survival rates of

729 the pelagic early life history stages of marine fish. Canadian Journal of Fisheries and $730 \quad$ Aquatic Sciences 48(3): 503-518.

731 Plattner, S., D. M. Mason, G. A. Leshkevich, D. J. Schwab, and E. S. Rutherford. 2006.

732 Classifying and forecasting coastal upwellings in Lake Michigan using satellite derived 733 temperature images and buoy data. J. Great Lakes Res. 32: 63-76.

734 Pothoven, S. A. and C. P. Madenjian. 2008. Changes in consumption by alewives and lake 735 whitefish after dreissenid mussel invasions in Lakes Michigan and Huron. North 736 American Journal of Fisheries Management 28: 308-320.

737 Pothoven, S. A. and G. L. Fahnenstiel. 2015. Spatial and temporal trends in zooplankton assemblages along a nearshore to offshore transect in southeastern Lake Michigan from 2007 to 2012. Journal of Great Lakes Research 41: 95-103.

Pritt, J. J., E. F. Roseman, and T. P. O’Brien. 2014. Mechanisms driving recruitment variability in fish: Comparisons between the Laurentian Great Lakes and marine systems. ICES Journal of Marine Science 71: 2252-2267. 
743 Quist, M. C., M. A. Pegg, and D. R. DeVries. 2012. Age and growth. Pages 677-731 in A. V.

744 Zale, D. L. Parrish, and T. M. Sutton, editors. Fisheries techniques, $3^{\text {rd }}$ edition.

$745 \quad$ American Fisheries Society, Bethesda, Maryland.

746 Rice, J. A., L. B. Crowder, and F. P. Binkowski. 1985. Evaluating otolith analysis for bloater 747 Coregonus hoyi: do otoliths ring true? Transactions of the American Fisheries Society $748 \quad 114: 532-539$.

749 Rice, J. A., L. B. Crowder, and M. E. Holey. 1987a. Exploration of mechanisms regulating larval

Rice, J. A., L. B. Crowder, and F. P. Binkowski. 1987b. Evaluating potential sources of mortality survival in Lake Michigan bloater: A recruitment analysis based on characteristics of individual larvae. Transactions of the American Fisheries Society 116: 703-718.

for larval bloater (Coregonus hoyi): Starvation and vulnerability to predation. Canadian Journal of Fisheries and Aquatic Sciences 44: 467-472.

Rowe, M. D., E. J. Anderson, J. Wang, and H. A. Vanderploeg. 2015. Modeling the effect of invasive quagga mussels on the spring phytoplankton bloom in Lake Michigan. Journal of Great Lakes Research 41: 49-65.

Schael, D. M., L. G. Rudstam, and J. R. Post. 1991. Gape limitation and prey selection in larval yellow perch (Perca flavescens), freshwater drum (Aplodinotus grunniens), and black crappie (Pomoxis nigromaculatus). Canadian Journal of Fisheries and Aquatic Sciences 48: 1919-1925.

Thayer, S. A. and A. J. Loftus. 2012. Great Lakes recreational fisheries and their role in fisheries management and policy. Pages 399-440 In Great Lakes Fisheries Policy and

764 Management. W. W. Taylor, editor. Michigan State University Press. 
Tsehaye, I., M. L. Jones, J. R. Bence, T. O. Brenden, C. P. Madenjian, and D. M. Warner 2014.

766

767

768

769

770

771

772

773

774

775

776

777

778

779

780

781

782

783

784

785

786

787

A multispecies statistical age-structured model to assess predator-prey balance: application to an intensively managed Lake Michigan pelagic fish community. Canadian Journal of Fisheries and Aquatic Sciences 71: 627-644.

Vanderploeg, H. A., J. R. Liebig, T. F. Nalepa, G. L. Fahnenstiel, and S. A. Pothoven. 2010. Dreissena and the disappearance of the spring phytoplankton bloom in Lake Michigan. Journal of Great Lakes Research 36: 50-59.

Warner, D. M., and B. M. Lesht. 2015. Relative importance of phosphorus, invasive mussels and climate for patterns in chlorophyll a and primary production in Lakes Michigan and Huron. Freshwater Biology 60: 1029-1043.

Warner, D. M., B. Turschak, D. Hanson, T. Desorcie, T. P. O'Brien, P. Armenio, and J. Smith. 2018. Status of pelagic prey fish in Lake Michigan, 2017. A report to the Great Lakes Fishery Commission, Lake Michigan Committee, Sault Ste. Marie, ON, March, 2018.

Wang, J., X. Bai, H. Hu, A. Clites, M. Colton, and B. Lofgren. 2012. Temporal and spatial variability of Great Lakes ice cover, 1973-2010. Journal of Climate 25: 1318-1329.

Weber, M. J., J. M. Dettmers, and D. H. Wahl. 2011. Growth and survival of age-0 yellow perch across habitats in southwestern Lake Michigan: Early life history in a large freshwater environment. Transactions of the American Fisheries Society 140: 1172-1185.

Weber, M. J., B. C. Ruebush, S. M. Creque, R. A. Redman, S. J. Czesny, D. H. Wahl, and J. M. Dettmers. 2015. Early life history of alewife Alosa pseudoharengus in southwestern Lake Michigan. Journal of Great Lakes Research 41: 436-447.

Wells, L. 1966. Seasonal and depth distribution of larval bloaters (Coregonus hoyi) in southeastern Lake Michigan. Transactions of the American Fisheries Society 95: 388- 
789 Withers, J. L., T. M. Sesterhenn, C. J. Foley, C. D. Troy, and T. O. Höök. 2015. Diets and 790 growth potential of early stage larval yellow perch and alewife in a nearshore region of 791 southeastern Lake Michigan. Journal of Great Lakes Research 41: 197-209.

792 Wood, S. N. 2006. Generalized additive models: an introduction with R. CRC press.

793 Wood, S. N. 2008. Fast stable direct fitting and smoothness selection for generalized additive 794 models. Journal of the Royal Statistical Society: Series B (Statistical Methodology) 70: $795 \quad 495-518$.

796 Yousef, F., R. Shuchman, M. Sayers, G. Fahnenstiel, and A. Henareh. 2017. Water clarity of the 797 upper Great Lakes: Tracking changes between 1998-2012. Journal of Great Lakes $798 \quad$ Research 43: 239-247. 
Table 1: Summary of larval Alewife and Bloater densities, daily growth rates, and percent empty stomachs across 24 Lake Michigan sampling sites from July 8-27, 2015. N (in parentheses) represents the total number of stomachs analyzed for diets.

\begin{tabular}{|c|c|c|c|c|c|c|c|c|}
\hline Transect name & $\begin{array}{c}\text { Sampling } \\
\text { Date }\end{array}$ & $\begin{array}{c}\text { Depth } \\
\text { (m) }\end{array}$ & $\begin{array}{c}\text { Alewife } \\
\text { Density } \\
\left(\mathbf{n} / 100 \mathbf{~ m}^{3}\right)\end{array}$ & $\begin{array}{c}\text { Alewife } \\
\text { Mean } \\
\text { Growth rate } \\
(\mathrm{mm} / \mathrm{d})\end{array}$ & $\begin{array}{c}\text { Alewife \% } \\
\text { empty } \\
\text { stomachs (N) }\end{array}$ & $\begin{array}{c}\text { Bloater } \\
\text { Density } \\
\left(\mathbf{n} / \mathbf{1 0 0 m ^ { 3 }}\right)\end{array}$ & $\begin{array}{l}\text { Bloater Mean } \\
\text { Growth Rate } \\
\quad(\mathbf{m m} / \mathbf{d})\end{array}$ & $\begin{array}{c}\text { Bloater \% } \\
\text { empty } \\
\text { stomachs }(\mathrm{N})\end{array}$ \\
\hline \multirow[t]{3}{*}{ Frankfort, MI } & July 8 & 18 & 0 & $\mathrm{n} / \mathrm{a}$ & $\mathrm{n} / \mathrm{a}$ & 0 & $\mathrm{n} / \mathrm{a}$ & $\mathrm{n} / \mathrm{a}$ \\
\hline & July 8 & 46 & 0.09 & $\mathrm{n} / \mathrm{a}$ & $100(1)$ & 0 & $\mathrm{n} / \mathrm{a}$ & $\mathrm{n} / \mathrm{a}$ \\
\hline & July 9 & 110 & 0 & $\mathrm{n} / \mathrm{a}$ & $\mathrm{n} / \mathrm{a}$ & 0.07 & 0.05 & $100(1)$ \\
\hline \multirow[t]{3}{*}{ Ludington, MI } & July 11 & 18 & 0.08 & $\mathrm{n} / \mathrm{a}$ & $100(1)$ & 0 & $\mathrm{n} / \mathrm{a}$ & $\mathrm{n} / \mathrm{a}$ \\
\hline & July 11 & 46 & 0.21 & 0.41 & $67(3)$ & 0.21 & 0.18 & $33(3)$ \\
\hline & July 12 & 110 & 0.32 & 0.35 & $60(5)$ & 0.38 & 0.17 & $43(7)$ \\
\hline \multirow[t]{3}{*}{ Saugatuck, MI } & July 12 & 18 & 11.96 & 0.39 & $70(40)$ & 0 & $\mathrm{n} / \mathrm{a}$ & $\mathrm{n} / \mathrm{a}$ \\
\hline & July 13 & 46 & 3.24 & 0.45 & $78(18)$ & 0.06 & 0.24 & $0(1)$ \\
\hline & July 16 & 110 & 1.87 & 0.56 & $48(31)$ & 1.16 & 0.21 & $15(20)$ \\
\hline \multirow[t]{3}{*}{ St Joseph, MI } & July 18 & 18 & 25.93 & 0.51 & $90(20)$ & 0 & $\mathrm{n} / \mathrm{a}$ & $\mathrm{n} / \mathrm{a}$ \\
\hline & July 16 & 46 & 42.57 & 0.58 & $65(34)$ & 0.25 & 0.24 & $0(2)$ \\
\hline & July 19 & 110 & 8.85 & 0.58 & $86(21)$ & 0.83 & 0.17 & $29(14)$ \\
\hline
\end{tabular}




\begin{tabular}{|c|c|c|c|c|c|c|c|c|}
\hline \multirow[t]{3}{*}{ Waukegan, IL } & July 19 & 18 & 0.32 & 0.58 & 100 (3) & 0 & $\mathrm{n} / \mathrm{a}$ & $\mathrm{n} / \mathrm{a}$ \\
\hline & July 20 & 46 & 2.84 & 0.44 & $90(10)$ & 0 & $\mathrm{n} / \mathrm{a}$ & $\mathrm{n} / \mathrm{a}$ \\
\hline & July 21 & 91 & 15.44 & 0.49 & $21(38)$ & 0.34 & 0.27 & $0(6)$ \\
\hline \multirow[t]{3}{*}{ Racine, WI } & July 22 & 18 & 1.50 & 0.48 & 82 (17) & 0 & $\mathrm{n} / \mathrm{a}$ & $\mathrm{n} / \mathrm{a}$ \\
\hline & July 22 & 46 & 1.68 & 0.47 & $85(26)$ & 0 & $\mathrm{n} / \mathrm{a}$ & $\mathrm{n} / \mathrm{a}$ \\
\hline & July 23 & 91 & 6.23 & 0.44 & $60(35)$ & 1.12 & 0.27 & $0(20)$ \\
\hline \multirow[t]{3}{*}{ Manitowoc, WI } & July 25 & 18 & 0 & $\mathrm{n} / \mathrm{a}$ & $\mathrm{n} / \mathrm{a}$ & 0.08 & 0.20 & $0(1)$ \\
\hline & July 25 & 46 & 0 & $\mathrm{n} / \mathrm{a}$ & $\mathrm{n} / \mathrm{a}$ & 0 & $\mathrm{n} / \mathrm{a}$ & $\mathrm{n} / \mathrm{a}$ \\
\hline & July 24 & 110 & 3.55 & 0.51 & $100(10)$ & 0.17 & 0.27 & $0(3)$ \\
\hline Sturgeon Bay, & July 26 & 18 & 0 & $\mathrm{n} / \mathrm{a}$ & $\mathrm{n} / \mathrm{a}$ & 0 & $\mathrm{n} / \mathrm{a}$ & $\mathrm{n} / \mathrm{a}$ \\
\hline \multirow[t]{2}{*}{ WI } & July 26 & 46 & 0 & $\mathrm{n} / \mathrm{a}$ & $\mathrm{n} / \mathrm{a}$ & 0.07 & 0.09 & $0(1)$ \\
\hline & July 27 & 110 & 0 & $\mathrm{n} / \mathrm{a}$ & $\mathrm{n} / \mathrm{a}$ & 0.11 & 0.12 & $50(2)$ \\
\hline
\end{tabular}


Table 2: Summary of Akaike’s Information Criterion, corrected for small sample size (AICc), for Generalized Additive Models seeking to explain variation in larval Alewife density with sitespecific water temperature (Temperature), CHL, and zooplankton density (Zooplankton) as explanatory variables. Models with $\triangle \mathrm{AICc}<6$ are summarized, and " $\mathrm{X}$ " indicates the variable was included in the model. Weight is scaled from $0-1$ and estimates the probability that a given model is actually the best, among all models considered.

\begin{tabular}{|c|c|c|c|c|c|c|c|}
\hline Temperature & CHL & Zooplankton & $\mathrm{df}$ & $\log L i k$ & AICc & $\triangle \mathrm{AICc}$ & Weight \\
\hline & & & 2 & -89.084 & 182.739 & 0.000 & 0.257 \\
\hline \multirow[t]{3}{*}{$\mathrm{X}$} & & & 3 & -88.056 & 183.311 & 0.572 & 0.193 \\
\hline & & $\mathrm{X}$ & 3 & -87.734 & 183.333 & 0.594 & 0.191 \\
\hline & $X$ & & 3 & -88.445 & 184.091 & 1.352 & 0.131 \\
\hline $\mathrm{X}$ & $\mathrm{X}$ & & 4 & -87.537 & 185.179 & 2.440 & 0.076 \\
\hline \multirow[t]{2}{*}{$X$} & & $\mathrm{X}$ & 4 & -87.566 & 185.286 & 2.546 & 0.072 \\
\hline & $\mathrm{X}$ & $\mathrm{X}$ & 4 & -87.707 & 185.615 & 2.877 & 0.061 \\
\hline$X$ & $\mathrm{X}$ & $X$ & 5 & -87.272 & 187.877 & 5.138 & 0.020 \\
\hline
\end{tabular}


Table 3: Summary of Akaike’s Information Criterion, corrected for small sample size (AICc), for Generalized Additive Models seeking to explain variation in mean larval Alewife growth rates with mean age (Age), site-specific zooplankton density (Zooplankton), alewife density (Density), and water temperature (Temperature) as explanatory variables. Only models with $\Delta \mathrm{AICc}<6$ are summarized, and " $\mathrm{X}$ " indicates the variable was included in the model. Alewife density and temperature were not listed in the table because those variables were only included in models with $\triangle \mathrm{AICc}>6$. Weight is scaled from $0-1$ and estimates the probability that a given model is actually the best, among all models considered.

\begin{tabular}{ccccccc} 
Age & Zooplankton & df & logLik & AICc & $\Delta$ AICc & Weight \\
& & & & & & \\
\hline $\mathrm{X}$ & $\mathrm{X}$ & 5 & 35.015 & -47.573 & 0.000 & 0.675 \\
$\mathrm{X}$ & & 4 & 29.093 & -45.485 & 2.089 & 0.238 \\
& & & & & & \\
& $\mathrm{X}$ & 3 & 27.614 & -43.489 & 4.085 & 0.088 \\
\hline
\end{tabular}


Table 4: Summary of Akaike’s Information Criterion, corrected for small sample size (AICc), for Generalized Additive Models seeking to explain variation in larval Bloater density with sitespecific water temperature (Temperature), CHL, and zooplankton density (Zooplankton) as explanatory variables. Models with $\triangle \mathrm{AICc}<6$ are summarized, and " $\mathrm{X}$ " indicates the variable was included in the model. Weight is scaled from $0-1$ and estimates the probability that a given model is actually the best, among all models considered.

\begin{tabular}{|c|c|c|c|c|c|c|c|}
\hline Temperature & CHL & Zooplankton & $\mathrm{df}$ & $\log L i k$ & AICc & $\triangle \mathrm{AICc}$ & Weight \\
\hline & & & 2 & -7.988 & 20.548 & 0.000 & 0.427 \\
\hline & & $\mathrm{X}$ & 3 & -7.587 & 22.375 & 1.826 & 0.171 \\
\hline $\mathrm{X}$ & & & 3 & -6.783 & 22.497 & 1.948 & 0.161 \\
\hline & $\mathrm{X}$ & & 3 & -7.986 & 23.172 & 2.624 & 0.115 \\
\hline $\mathrm{X}$ & & $\mathrm{X}$ & 4 & -6.954 & 25.014 & 4.465 & 0.045 \\
\hline & $\mathrm{X}$ & $\mathrm{X}$ & 4 & -7.530 & 25.165 & 4.616 & 0.042 \\
\hline$X$ & $X$ & & 4 & -6.787 & 25.456 & 4.908 & 0.037 \\
\hline
\end{tabular}


Table 5: Modal Alewife hatch date from eight Lake Michigan transects (pooling larvae captured across all depths) and corresponding water temperatures from nearshore (assuming all alewife hatch in this region). Note that we only sampled larvae once in July, so actual peak of hatching is unknown.

\begin{tabular}{lcc}
\hline & & \\
Port name & Modal hatch date & Temperature $\left({ }^{\circ} \mathrm{C}\right)$ \\
\hline & $\mathrm{n} / \mathrm{a}$ & $\mathrm{n} / \mathrm{a}$ \\
Frankfort, MI & June 30 & 15.83 \\
Ludington, MI & June 24 & 18.93 \\
Saugatuck, MI & June 25 & 18.84 \\
St. Joseph, MI & July 12 & 17.22 \\
Waukegan, IL & July 12 & 17.16 \\
Racine, WI & July 10-11, 13-14 & $15.56-18.50$ \\
Manitowoc, WI & n/a & n/a \\
Sturgeon Bay, WI & & \\
\hline
\end{tabular}


Figure legends

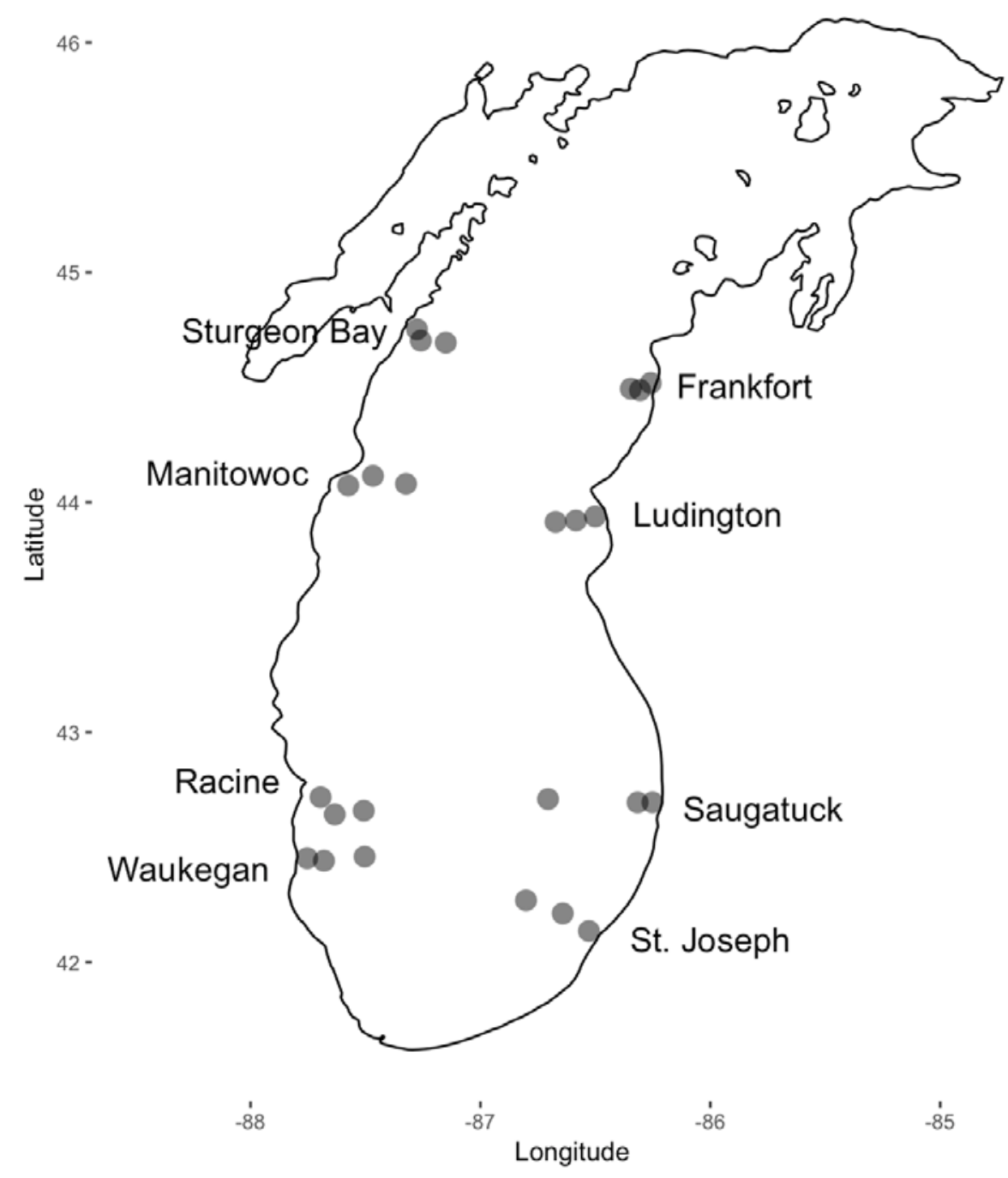

Figure 1: Location of sites where larval fish and associated environmental variables were sampled from July 8-27, 2015 in Lake Michigan. 


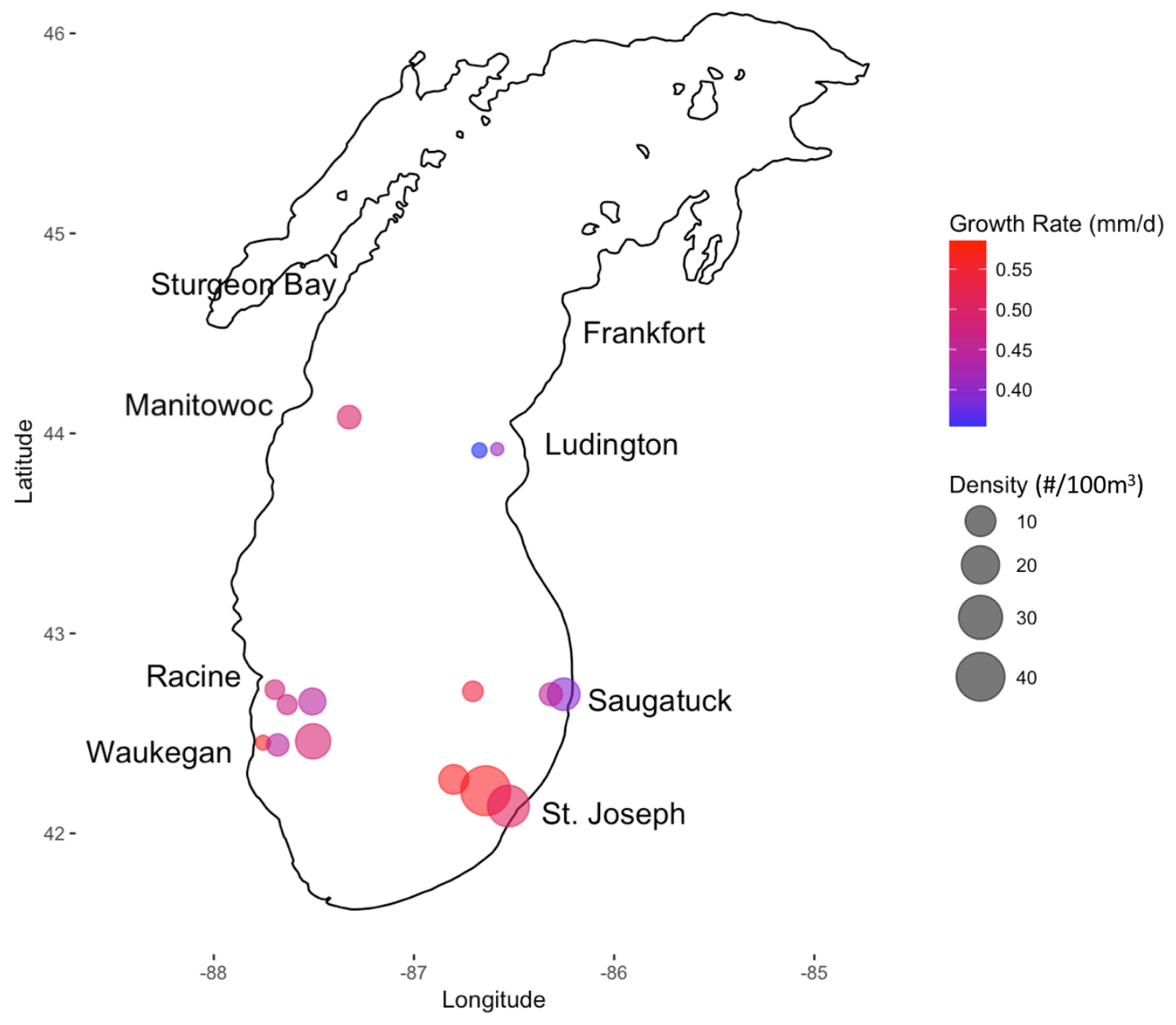

Figure 2: Larval Alewife average growth rates (circle color) and average densities (circle size) at each of our sampling locations from July 8-27, 2015 in Lake Michigan. 

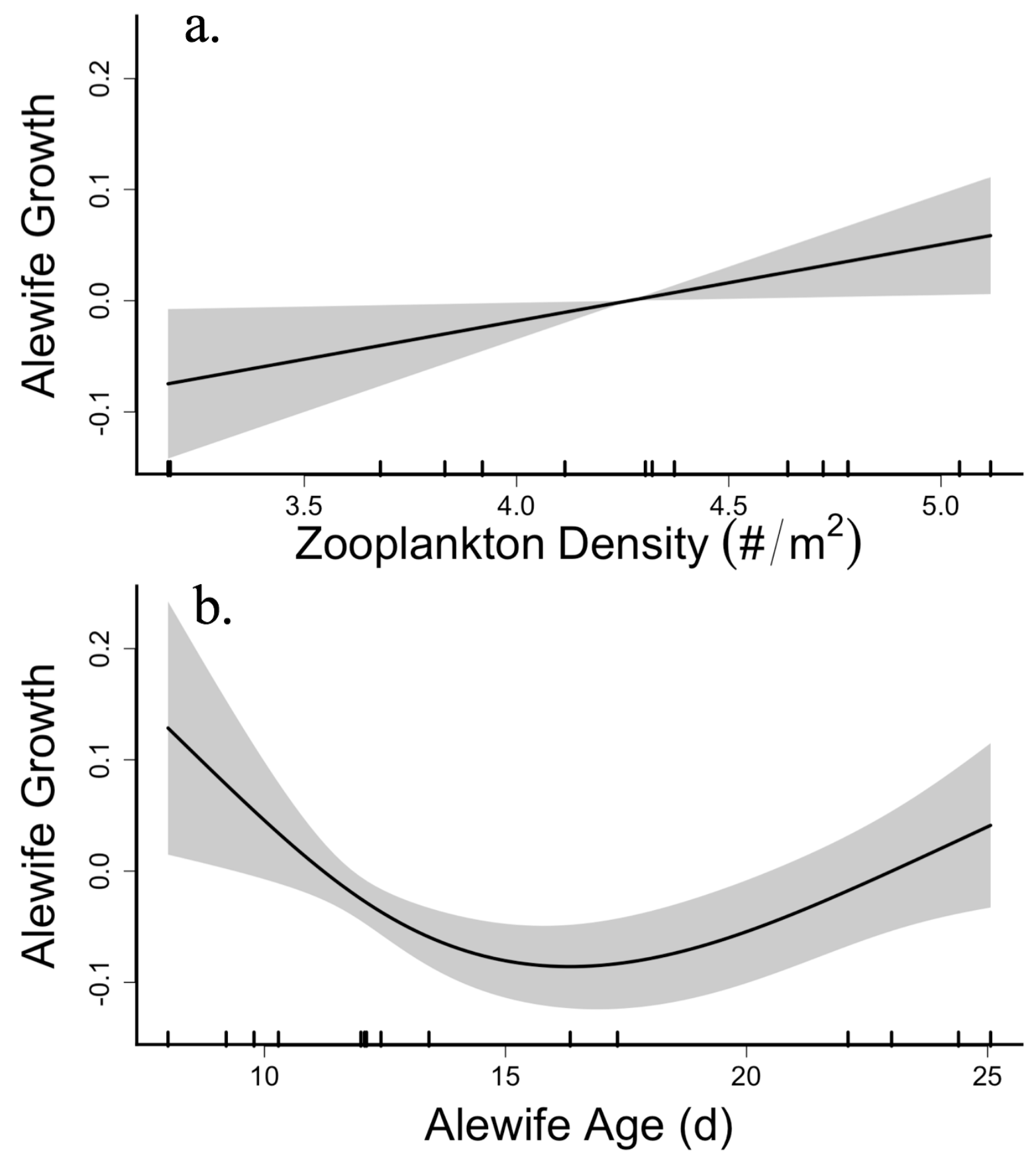

Figure 3: Predicted larval Alewife growth (mm/d) in Lake Michigan between July 8-27, 2015 as

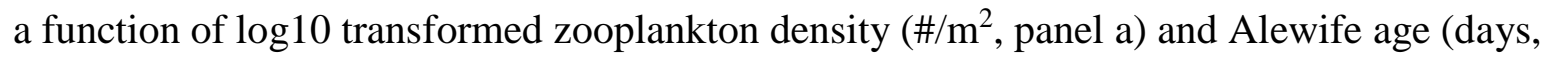
panel b) using a generalized additive model. In each panel, the shaded area represents the 95\% confidence interval. Dashes above the x-axis represent the distribution of data points. 


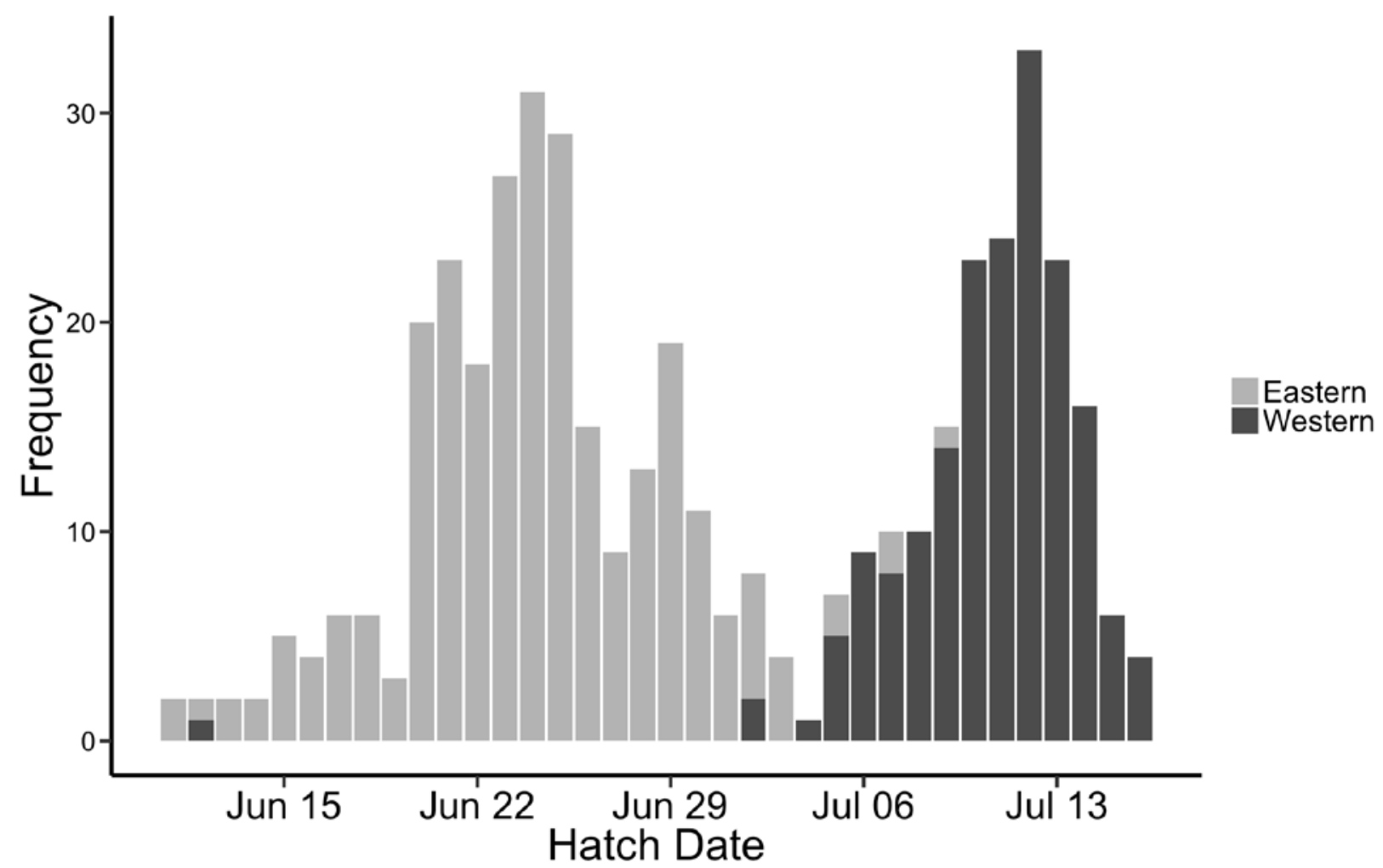

Figure 4: Frequency distribution of 2015 Alewife hatch date (day of capture - estimated age) for a subset of larvae randomly selected for otolith age processing. Frankfort, Ludington, Saugatuck, and St. Joseph were pooled under eastern Lake Michigan (gray), and Waukegan, Racine, Manitowoc, and Sturgeon Bay were pooled under western Lake Michigan (black). 
Supplementary Table 1.

Mean diet percentage (by count) and frequency of occurrence for prey taxa identified in larval alewife ( $\mathrm{n}=104$, table A) and bloater $(\mathrm{n}=68$, table $\mathrm{B}$ ) sampled in Lake Michigan across 24 sites between July 8-27, 2015. On average, larval Alewife were sampled at 0049 hours, whereas larval Bloater were sampled at 0154 hours.

\begin{tabular}{|l|c|c|}
\hline \multicolumn{2}{|c|}{ \% in the diet } & Frequency of occurrence \\
\hline \multicolumn{1}{|c|}{ A) Alewife } & 39.2 & 55.7 \\
\hline Dreissenid veliger & 27.8 & 47.1 \\
\hline Unidentified copepod & 13.3 & 24.0 \\
\hline Cyclopoid copepodite & 5.5 & 9.6 \\
\hline Calanoid copepodite & 4.5 & 5.7 \\
\hline Leptodiaptomus minutus & 3.2 & 3.8 \\
\hline Bosmina spp. & 1.9 & 1.9 \\
\hline Polyphemus pediculus & 1.9 & 1.9 \\
\hline Diacyclops thomasi & 1.0 & 1.0 \\
\hline Copepod nauplii & 0.7 & 1.0 \\
\hline Conochilus spp. & 0.6 & 2.9 \\
\hline Leptodiaptomus ashlandi & 0.5 & 1.0 \\
\hline Leptodiaptomus sicilis & & \\
\hline B) Bloater & & \\
\hline Unidentified copepod & & \\
\hline Cyclopoid copepodite & & \\
\hline Dreissenid veliger & & \\
\hline
\end{tabular}




\begin{tabular}{|l|c|c|}
\hline Calanoid copepodite & 4.5 & 25.0 \\
\hline Diacyclops thomasi & 2.3 & 11.8 \\
\hline Bosmina spp. & 2.1 & 16.2 \\
\hline Polyphemus pediculus & 1.5 & 8.8 \\
\hline Leptodora kindtii & 0.8 & 2.9 \\
\hline Leptodiaptomus minutus & 0.2 & 2.9 \\
\hline Keratella spp. & 0.1 & 1.5 \\
\hline $\begin{array}{l}\text { Bythotrephes longimanus }\left(1^{\text {st }}\right. \\
\text { instar })\end{array}$ & $<0.01$ & 1.5 \\
\hline Epischura lacustris & $<0.01$ & 1.5 \\
\hline
\end{tabular}

